\title{
Evaluation of Rice Genotypes for Genetic Variability, Heritability and Genetic Advance in Saline and Normal soil Conditions
}

\author{
Anuj Kumar ${ }^{1 *}$, D. K. Dwivedi ${ }^{1}$, Pradeep K. Bharti ${ }^{1}$, Vineeta Singh ${ }^{1}$, \\ Preeti Kumari $^{2}$, Archana Devi ${ }^{2}$, and N. A. Khan ${ }^{1}$ \\ ${ }^{1}$ Department of Plant Molecular Biology \& Genetic Engineering, ${ }^{2}$ Department of Genetics \\ and Plant Breeding, A. N. D. University of Agriculture \& Technology, Kumar Ganj, \\ Ayodhya-224229, India \\ *Corresponding author
}

\section{A B S T R A C T}

\begin{tabular}{l} 
K e y w o r d s \\
$\begin{array}{l}\text { Genetic variability, } \\
\text { Heritability, } \\
\text { Genetic advance, } \\
\text { Rice } \\
\text { (Oryza sativa L.) }\end{array}$ \\
\hline $\begin{array}{l}\text { Article Info } \\
\text { Accepted: } \\
\text { 22 June } 2020 \\
\text { Available Online: } \\
\text { 10 July } 2020\end{array}$ \\
\hline
\end{tabular}

\section{Keywords}

Heritability,

Genetic advance,

Rice

\section{Article Info}

Accepted:

22 June 2020

10 July 2020
The present investigation was carried out with the objectives to estimate genetic variability for yield and yield contributing components. The investigation consisted of twenty rice genotypes and the experiment was conducted during Kharif-2018-19 in Randomized Block Design with three replications. The data were recorded for fourteen quantitative characters to study genetic variability, heritability and genetic advance. Analysis of variance among twenty genotypes showed significant difference for all characters under studied. Highest genotypic coefficient of variation (GCV) and phenotypic coefficient variation (PCV) was observed for grains per panicle followed by panicle bearing tillers per plant and spikelets per panicle in controlled condition, whereas, in saline condition highest genotypic coefficient of variation (GCV) and phenotypic coefficient variation (PCV) was observed for panicle bearing tillers per plant followed by grains per panicle and spikelets per panicle. These characters could be used as selection parameters for crop improvement. High estimates of heritability were observed for $\mathrm{K}^{+}$followed by plant height, days to $50 \%$ flowering, harvest index\% and grains per panicle in normal soil condition, whereas, in saline condition highest broad sense heritability was recorded in the case of plant height, spikelets per panicle followed by days to $50 \%$ flowering, grains per panicle, $\mathrm{K}^{+}$and harvest index \%. In controlled condition high genetic advance were observed for grains per panicle followed by spikelets per panicle, whereas, in saline condition maximum genetic advances was recorded in grains per panicle followed by panicle bearing tillers per plant. It indicated that the presence of additive gene action. Hence, emphasis should be given to select these quantitative traits to enhance the yield potential of rice (Oryza sativa L.) under both conditions.

\section{Introduction}

Rice (Oryza sativa L.) is a diploid $(2 \mathrm{n}=24)$ and self-fertilized monocot. There are two species of cultivated rice - Oryza sativa and
Oryza glaberrima. Oryza sativa is the rice cultivated in majority of rice growing countries. As a food crop, it forms the staple food of more than three billion people accounting for about $50-80 \%$ of their daily 
calorie intake (Khush 2005). Rice protein is biologically richest as its digestibility is extremely high (88\%). It is the 2 nd most vital crop within the world after wheat, covering almost $90 \%$ of area across Asia alone. The use of the crop varies widely starting from its use as food in cereals, snacks, brewed beverages, flour, rice bran oil to its use in religious events across India. Asia is the largest producer of rice $(90 \%)$ with an average productivity 3.9 tonnes per hectare. China and India account for about $50 \%$ of the world's rice area and $56 \%$ of production (Hossain and Pingali, 1998). Rice is a most important cereal crop in India and it contributes about $45 \%$ to the cereal production, $41 \%$ of the total food grain production and accounts for $20-25$ per cent of the agricultural GDP. In India, rice occupies 43.90-million-hectare area with total production of 109 million ton with productivity of 2.59 ton/hectare. Global rice production was only 483.9 million tonnes in (2017-18). Rice is cultivated worldwide over an area of about 153.51 million hectares with annual production of 650.19 million tonnes. The production of rice in U.P. is 12.51 million tonnes (Press Information Bureau, Government of India, 2017). India ranked first in area having 45.2 million hectares and second in production 104.32 million tonnes. (CSSRI Annual Report, 2017-18). Abiotic stress is a major factor around the world limiting plant growth and productivity. Salinity may be a serious environmental constraint to crop production in many parts of the planet. It is especially prevalent in irrigated agriculture and in marginal lands, associated with poor drainage or high-water tables. Estimates for the extent of salinity damage vary from 25-50 percent of the world's irrigated land. The development of crops/varieties with improved salt tolerance is proposed as part of the solution to these problems. A soil can be termed as saline if its $\mathrm{EC}$ is $4 \mathrm{dS} / \mathrm{m}$ or more (USDA-ARS 2008), (equivalent to approximately $40 \mathrm{mM} \mathrm{NaCl}$ ) with an osmotic pressure of approximately 0.2 MPa. Salinity is that the condition when the EC is sufficient to cause yield reduction of most crops. The $\mathrm{pH}$ of saline soils generally ranges from 7- 8.5 (Mengel et al., 2001). Salinity prone areas found in the arid and semiarid zones are usually accounted to the accumulation of salts over ages. It has been well documented that the effect of salinity on seedling growth, seedling establishment, grain yield components like spikelet number, tiller number has successively led to a reduction in grain yield (Khatun et al., 1995; and Zeng et al., 2003).

\section{Materials and Methods}

\section{Plant materials}

A total of twenty rice genotypes were used in this study, which were IR68144-2B-2-2-3-1120, IR-68144-2B-2-2-3-1-127, IR-91167-991-1-1-3, IR-91167-133-1-1-2-3, NUD-3, NDR-359, IR-28, FL-478, NUD-2, CSR-13, AYYAR, NDRK-2008, IR-64, SWARNA, IR-92953-49-1-3, IR-91171-66-3-2-1-3, IR83668-35-2-2-2, SAMBHA MANSURI, TARAMON and MTU-1010.

\section{Screening of rice genotypes at the reproductive stage}

The genotypes were evaluated for their tolerance to salinity under net house of Department of PMB\&GE, A. N. D. U. A. T. Kumar Ganj, Ayodhya using standard protocol (Gregorio et al., 1997). The experimental design was completely randomized block design with three replications. Two setups were maintained: normal and salinized. Pregerminated seeds of rice genotypes were planted in earthen pots. After 2 weeks, seedlings were thinned and the water level was raised to about $1 \mathrm{~cm}$. The pots were salinized at EC $6 \mathrm{dSm}-1$ three weeks 
after sowing and EC was monitored in every week. Data were recorded for days to $50 \%$ flowering, Plant height $(\mathrm{cm})$, Panicle bearing tillers per plant, Panicle length $(\mathrm{cm})$, Number of spikelets per panicle, Number of grains per panicle, Spikelet fertility (\%), Test weight(g), Biological yield/plant (g), Harvest index (\%), $\mathrm{Na}+/ \mathrm{K}+$ ratio and Grain yield/plant (g) and data was subjected to statistical analysis. The variance was estimated as per procedure as suggested by Panse and Sukhatme (1967), PCV and GCV were calculated by the formula given by Burton (1952), heritability in broad sense (h2) by Burton and De Vane (1953) and genetic advance i.e. the expected genetic gain were calculated by using the procedure given by Johnson et al., (1955).

\section{Results and Discussion}

Genetic variability in any crop is prerequisite for selection of superior genotypes over the prevailing cultivars. The analysis of variance for different characters indicated the existence of highly significant differences for all fourteen characters under study at $1 \%$ level of significance suggesting each and every genotype are genetically divergent from each other and there is ample scope for selection of characters from these diverse sources for yield and its components both the conditions (normal and treated) (Table 1a, and 2a). These findings were in accordance with the findings of Bekele et al., (2013) and Sandhya et al., (2015). Wide range of variance was observed for all the characters. Phenotypic variance was higher than genotypic variance for all the yield and its contributing characters indicate the influence of environmental factors on these traits. Under control condition the grains per panicle $(23.94 \%)$ showed highest phenotypic coefficient of variation followed by panicle bearing tillers per plant $(22.14 \%)$, spiklets per panicle $(21.95 \%), \quad \mathrm{Na}^{+} / \mathrm{K}^{+}$ (21.83\%), grain yield per plant $(19.14 \%)$, plant height $(\mathrm{cm})(18.66 \%)$. Under saline condition the panicle bearing tillers per plant (32.34 \%) showed highest phenotypic coefficient of variation followed by grains per panicle $(27.53 \%)$, spikletes per panicle $(25.64 \%), \mathrm{K}^{+}(23.36 \%)$, grain yield per plant (g) $(16.76 \%), \mathrm{Na}^{+} / \mathrm{K}^{+}(15.74 \%)$, biological yield per plant $(\mathrm{g})(15.73 \%)$. Similar results were also reported by Anjaneyulu et al., (2010), Idris et al., (2012), Yadav et al., (2018) and Sandhya (2014). Coefficients of variation studies indicated that the estimates of PCV were slightly higher than the corresponding GCV (Table $1 \mathrm{~b}$ and $2 \mathrm{~b}$ ) among the all traits. Grains/panicle (23.94 and 21.29) exhibited high estimates of genotypic coefficient of variation (GCV) and phenotypic coefficient of variation (PCV) followed by panicle bearing tillers per plant (22.14 and 17.54), spiklets per panicle (21.95 and 21.29) in controlled condition, whereas, in saline condition panicle bearing tillers (32.34 and 29.53) exhibited high estimates of genotypic coefficient of variation (GCV) and phenotypic coefficient of variation (PCV) followed by grains/panicle (27.53 and 27.24), spiklets per panicle (25.64 and 25.30), high values of genotypic coefficient of variation $(\mathrm{GCV})$ and phenotypic coefficient of variation (PCV) for these traits suggested the possibility of yield improvement through selection of these traits. Close relationship between GCV and PCV was found altogether the characters and PCV values were slightly greater than GCV, revealing little or no influence of environment for expression. The amount of genetic variation considered alone will not be of much use to the breeder unless supplemented with the information on heritability estimate, which gives a measure of the heritable portion of the total variation. It has been suggested by Burton and Devane (1953) that the GCV along with heritability estimate could provide a better picture of the amount of advance to be expected by phenotypic selection. Since genetic advance is dependent on phenotypic variability and 
heritability in addition to selection intensity, the heritability estimates in conjunction with genetic advance will be more effective and reliable in predicting the response to selection. Heritability in broad sense includes both additive and non-additive gene effects. While, narrow sense heritability includes only additive components (Johnson et al., 1955).

In the present study, in controlled condition highest broad sense heritability was recorded in the case of $\mathrm{K}^{+}$(99.8) followed by plant height (99.40), days to $50 \%$ flowering (97.87), harvest index(\%) (97.48) and grains per panicle (95.16) (Table 1b) whereas, in saline condition highest broad sense heritability was recorded in the case of plant height (98.97) followed by days to $50 \%$ flowering (98.03) grains per panicle (97.96),
$\mathrm{K}^{+}$(97.87) and spikelet fertility (\%) (94.77) (Table 2b) Fiyaz et al., (2011), Dhanwani et al., (2013) and Yadav et al., (2018). Maximum genetic advance was recorded for grains per panicle (46.93) followed by spikelets per panicle (42.54) showed in (table 1b) in controlled condition, whereas, in saline condition maximum genetic advances was recorded ingrains per panicle (5.55) followed by panicle bearing tillers per plant (55.53) (Table2b) Tiwari et al., (2011). In general heritability along with genetic advance are often useful in selection programmes. High heritability with high genetic advance as percent of mean indicates that these characters are largely controlled by additive gene action, which indicates that improvement in these characters is possible through mass selection and progeny selection.

Table.1 (a) Analysis of variance for randomized block design for 14 characters of rice under controlled condition

\begin{tabular}{|c|c|c|c|}
\hline \multirow{3}{*}{ Characters } & \multicolumn{3}{|c|}{ Sources of variation } \\
\hline & Replication & Treatments & Error \\
\hline & 2 & 19 & 38 \\
\hline Days to $50 \%$ flowering & 0.47 & $108.81 * *$ & 1.16 \\
\hline Plant height (cm) & 0.62 & $1003.00 * *$ & 1.99 \\
\hline Panicle bearing tillers/plant & 1.11 & $4.63 * *$ & 0.76 \\
\hline Panicle length (cm) & 2.73 & $24.44 * *$ & 0.95 \\
\hline Spikelets/panicle & 58.31 & $3258.55^{* *}$ & 66.70 \\
\hline Grains/panicle & 14.40 & $2782.26 * *$ & 46.39 \\
\hline Spikelet fertility (\%) & 0.14 & $30.32 * *$ & 0.94 \\
\hline Test weight (g) & 0.20 & $16.52 * *$ & 0.31 \\
\hline Biological yield/plant (g) & 10.56 & $182.66^{* *}$ & 9.93 \\
\hline Harvest index (\%) & 1.31 & $64.26 * *$ & 0.54 \\
\hline $\mathrm{Na}^{+}$ & 0.02 & $0.61 * *$ & 0.04 \\
\hline $\mathbf{K}^{+}$ & 0.005 & $55.52 * *$ & 0.02 \\
\hline $\mathrm{Na}^{+} / \mathbf{K}^{+}$ & 0.000 & $0.002 * *$ & 0.000 \\
\hline Grain yield/plant (g) & 1.27 & $37.88^{* *}$ & 1.54 \\
\hline
\end{tabular}

*, ** significant at 5 and $1 \%$ probability levels, respectively 
Table.1 (b) Estimates of general mean, phenotypic coefficient of variability (PCV), genotypic coefficient of variability (GCV), heritability in broad sense $\left(h^{2} b\right)$ and genetic advance in percent of mean for 14 characters in rice in control condition

\begin{tabular}{|c|c|c|c|c|c|}
\hline \multirow[t]{2}{*}{ Characters } & \multirow[t]{2}{*}{$\begin{array}{l}\text { General } \\
\text { Mean } \pm \text { SE }\end{array}$} & \multicolumn{2}{|c|}{$\begin{array}{l}\text { Coefficient of variation } \\
(\%)\end{array}$} & \multirow{2}{*}{$\begin{array}{l}\text { Heritabilit } \\
y \text { in broad } \\
\text { sense }(\%)\end{array}$} & \multirow{2}{*}{$\begin{array}{l}\text { Genetic } \\
\text { advance } \\
\text { as \% of } \\
\text { mean }\end{array}$} \\
\hline & & PCV & GCV & & \\
\hline Days to $50 \%$ flowering & $93.98 \pm 0.60$ & 6.48 & 6.37 & 97.87 & 12.92 \\
\hline Plant height $(\mathbf{c m})$ & $86.14 \pm 2.26$ & 18.66 & 18.60 & 99.40 & 38.20 \\
\hline $\begin{array}{l}\text { Panicle bearing } \\
\text { tillers/plant }\end{array}$ & $11.90 \pm 1.04$ & 22.14 & 17.54 & 62.76 & 28.63 \\
\hline Panicle length $(\mathrm{cm})$ & $24.23 \pm 0.66$ & 14.13 & 13.34 & 89.14 & 25.95 \\
\hline Spikelets/panicle & $122.24 \pm 1.97$ & 21.95 & 21.29 & 94.10 & 42.54 \\
\hline Grains/panicle & $113.62 \pm 2.69$ & 23.94 & 23.35 & 95.16 & 46.93 \\
\hline Spikelet fertility (\%) & $92.61 \pm 1.83$ & 3.90 & 3.72 & 91.24 & 7.32 \\
\hline Test weight (g) & $20.43 \pm 0.60$ & 10.06 & 9.78 & 94.52 & 19.59 \\
\hline Biological yield/plant (g) & $31.83 \pm 1.45$ & 17.43 & 16.10 & 85.29 & 30.63 \\
\hline Harvest index (\%) & $40.96 \pm 2.32$ & 11.33 & 11.19 & 97.48 & 22.75 \\
\hline $\mathrm{Na}+$ & $3.36 \pm 0.24$ & 13.43 & 12.08 & 80.84 & 22.37 \\
\hline $\mathbf{K}+$ & $24.97 \pm 0.89$ & 15.54 & 15.53 & 99.80 & 31.97 \\
\hline $\mathrm{Na}+/ \mathbf{K}+$ & $0.14 \pm 0.01$ & 21.83 & 20.90 & 91.64 & 41.21 \\
\hline Grain yield/plant (g) & $12.70 \pm 0.72$ & 19.14 & 18.02 & 88.68 & 34.96 \\
\hline
\end{tabular}

Table.2 (a) Analysis of variance for randomized block design for 14 characters of rice under saline condition

\begin{tabular}{|c|c|c|c|}
\hline \multirow[t]{3}{*}{ Characters } & \multicolumn{3}{|c|}{ Sources of variation } \\
\hline & Replication & Treatments & Error \\
\hline & 2 & 19 & 38 \\
\hline Days to $50 \%$ flowering & 0.43 & $185.31 * *$ & 1.23 \\
\hline Plant height (cm) & 0.42 & $130.88 * *$ & 0.45 \\
\hline Panicle bearing tillers/plant & 0.62 & $7.42 * *$ & 0.46 \\
\hline Panicle length $(\mathrm{cm})$ & 2.31 & $28.28 * *$ & 1.66 \\
\hline Spikelets/panicle & 10.51 & $2832.35^{* *}$ & 25.20 \\
\hline Grains/panicle & 4.48 & $2284.54 * *$ & 15.75 \\
\hline Spikelet fertility (\%) & 1.37 & $35.60 * *$ & 0.64 \\
\hline Test weight (g) & 0.23 & $16.58^{* *}$ & 0.44 \\
\hline Biological yield/plant (g) & 7.08 & $63.74 * *$ & 2.88 \\
\hline Harvest index $(\%)$ & 2.59 & $52.46^{* *}$ & 2.13 \\
\hline $\mathrm{Na}^{+}$ & 0.01 & $0.76 * *$ & 0.07 \\
\hline $\mathbf{K}^{+}$ & 0.21 & $42.55^{* *}$ & 0.30 \\
\hline $\mathrm{Na}^{+} / \mathrm{K}^{+}$ & 0.0000 & $0.0023 * *$ & 0.0001 \\
\hline Grain yield/plant (g) & 1.19 & $9.15 * *$ & 0.46 \\
\hline
\end{tabular}

\footnotetext{
*, ** significant at 5 and $1 \%$ probability levels, respectively
} 
Table.2 (b) Estimates of general mean, phenotypic coefficient of variability (PCV), genotypic coefficient of variability (GCV), heritability in broad sense $\left(h^{2} b\right)$ and genetic advance in per cent of mean for 14 characters in rice in saline condition

\begin{tabular}{|l|c|c|c|c|c|}
\hline Characters & $\begin{array}{c}\text { General } \\
\text { Mean } \mathbf{\pm S E}\end{array}$ & \multicolumn{2}{|c|}{$\begin{array}{c}\text { Coefficient of variation } \\
(\boldsymbol{\%})\end{array}$} & $\begin{array}{c}\text { Heritability } \\
\text { in broad } \\
\text { sense (\%) }\end{array}$ & $\begin{array}{c}\text { Genetic } \\
\text { advance as \% } \\
\text { of mean }\end{array}$ \\
\cline { 2 - 5 } Days to 50 \% flowering & $101.73 \pm 1.31$ & 8.37 & 8.28 & 98.03 & 16.89 \\
\hline Plant height (cm) & $77.20 \pm 2.92$ & 7.38 & 7.34 & 98.97 & 15.04 \\
\hline $\begin{array}{l}\text { Panicle bearing } \\
\text { tillers/plant }\end{array}$ & $10.58 \pm 0.71$ & 32.34 & 29.53 & 83.36 & 55.53 \\
\hline Panicle length (cm) & $21.33 \pm 0.74$ & 14.78 & 13.57 & 84.22 & 25.65 \\
\hline Spikelets/panicle & $113.43 \pm 1.17$ & 25.64 & 25.30 & 97.38 & 51.43 \\
\hline Grains/panicle & $106.64 \pm 2.18$ & 27.53 & 27.24 & 97.96 & 55.55 \\
\hline Spikelet fertility (\%) & $93.24 \pm 0.77$ & 4.21 & 4.10 & 94.77 & 8.23 \\
\hline Test weight (g) & $19.12 \pm 0.60$ & 12.24 & 11.77 & 92.43 & 23.31 \\
\hline Biological Yield/Plant & $28.48 \pm 0.56$ & 15.73 & 14.72 & 87.56 & 28.37 \\
(g) & & & & & \\
\hline Harvest index (\%) & $39.99 \pm 1.29$ & 11.34 & 10.68 & 88.72 & 20.73 \\
\hline Na+ & $3.93 \pm 0.18$ & 13.87 & 13.72 & 75.62 & 27.96 \\
\hline K+ & $26.40 \pm 1.50$ & 23.36 & 21.80 & 97.87 & 41.90 \\
\hline Na+/K+ & $0.15 \pm 0.01$ & 15.74 & 14.62 & 87.09 & 27.96 \\
\hline Grain yield/plant (g) & $11.31 \pm 0.34$ & 16.76 & 14.57 & 86.25 & 26.10 \\
\hline
\end{tabular}

Fig Response of rice genotype under control and saline condition at reproductive stage
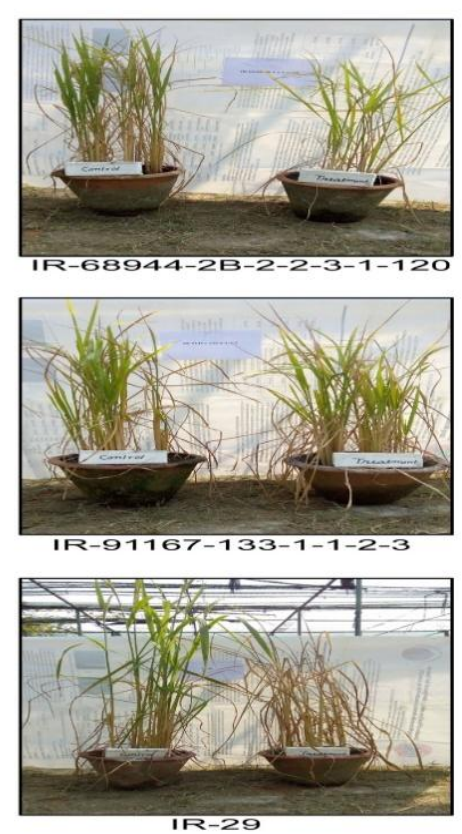
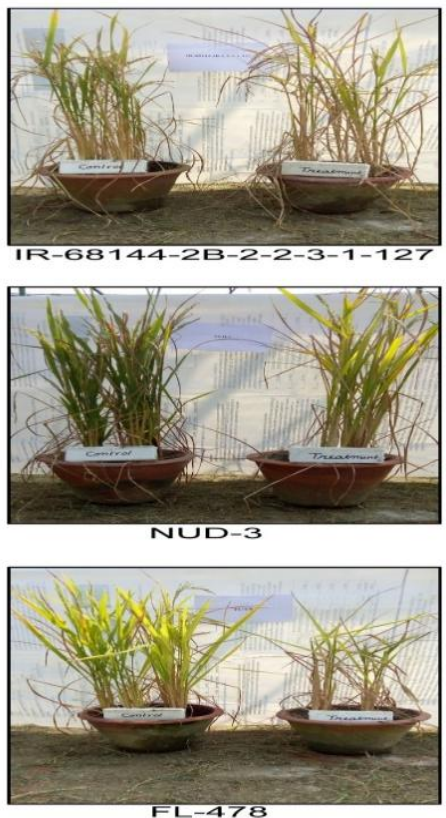
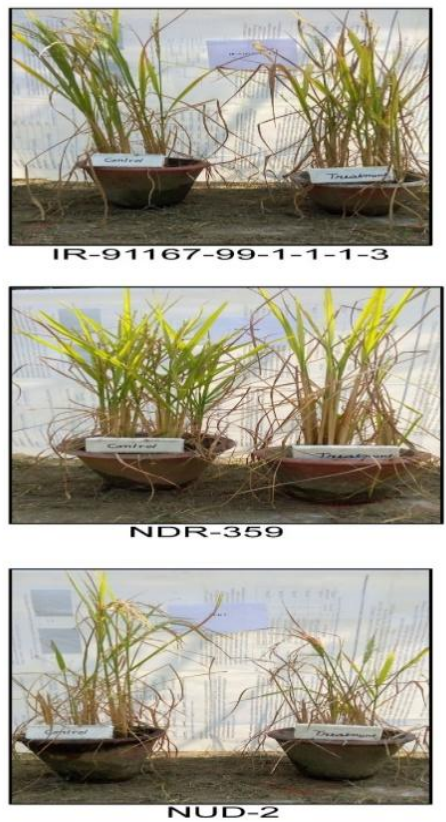
In conclusion this investigation included 20 genotypes of rice genotypes was carried out in order to study the nature and amount of variability, heritability and genetic advance for 14 quantitative characters. Analysis of variance among 20 genotypes showed significant difference for all characters studied. Highest genotypic coefficient of variation (GCV) and phenotypic coefficient variation $(\mathrm{PCV})$ was observed for grains per panicle followed by panicle bearing tillers per plant and spikelet per panicle in controlled condition, whereas, in saline condition highest genotypic coefficient of variation (GCV) and phenotypic coefficient variation (PCV) was observed for panicle bearing tillers per plant followed by grains per panicle and spikelets per panicle. These characters might be used as selection parameters for crop improvement. High estimates of heritability were observed for $\mathrm{K}^{+}$followed by plant height, days to $50 \%$ flowering, harvest index $\%$ and grains per panicle in controlled condition, whereas, in saline condition highest broad sense heritability was recorded in the case of plant height followed by spikelets per panicle, days to $50 \%$ flowering, grains per panicle, $\mathrm{K}^{+}$and harvest index $\%$. In controlled condition high genetic advance were observed for grains per panicle followed by spikelets per panicle, whereas, in saline condition maximum genetic advances was recorded in grains per panicle followed by panicle bearing tillers per plant indicating predominance of additive gene effects and possibilities of effective selection for the development of those characters.

\section{References}

Anjaneyulu M, Reddy D. R., Reddy H. P. (2010) Genetic variability, heritability and genetic advance inrice(Oryza sativa L.). Research on Crops. 11(2):415- 416.

Bekele B. D., Rakh S., Naveen G. K., Kundur P. J., Shashidhar H. E. (2013)
Estimation of genetic variability and correlation studies for grain zinc concentrations and yield related traits in selected rice (Oryza sativa L.) genotypes. Asian J. of Bio. Sci., 4(3):391-397.

Burton G. W., De Vane E. H. (1953) Estimating heritability in tall fescue from Replicated clone natural materials. Agronomy Journal., 45:171181.

CSSRI, (2017-18). Annual report central soil salinity research institute, Karnal.

Dhanwani R. K., Sarawgi A. K., Solanki A., Tiwari J. K. (2013) Genetic variability analysis for various yield attributing and quality traits in rice (Oryza sativa L.). The Bioscan 8(4):1403-1407.

Yadav P., Singh P., Harishchandra, Kumar G., Shivani, Khan N.A., Dwivedi D.K. (2018). Estimation of genetic variability, heritability and genetic advance of thirty rice (Oryza sativa L.) genotypes in saline and normal condition. Int. J. Cur. Microbial. App. Sci., 7: 1531-1539.

Fiyaz R. A., Ramya K. T., Chikkalingaiah, Ajay B. C., Gireesh C. and Kulkarni R. S. (2011) Genetic variability, correlation and path coefficient analysis studies in rice (Oryza sativa L.) under alkaline soil condition. Electronic Journal of Plant Breeding. 2(4):531537.

Gregorio G.B., Senadhira D. and Mendoza R.D. (1997) Screening rice for salinity tolerance. IRRI Discussion Paper Series no. 22. Manila (Philippines): IRRI.1-30.

Hossain M. and Pingali P.L. (1998) Rice research, technological progress, and impact on productivity and poverty: an overview. In: Impact of Rice Research.

Idris A. E., Justin F. J., Dagash M.I. andAbuali A. I. (2012) Genetic variability and inter relationship between yield and yield components in some rice genotypes. American Journal 
of Experimental Agriculture. 2(2):233239.

Johnson H.W., Robinson H.P. and Comstock R.E. (1955) Estimates of genetic and environmental variability in Soybeans. Agron. J., 47: 314-318.

Khatun S. and Flowers T. J. (1995) Effects of salinity on seed set in rice. Plant, Cell Envi. 18:61-67.

Khatun S., Rizzo C. A. and Flowers T. J. (1995) Genotypic variation in the effect of salinity on fertility in rice.Plant Soil 173: 239-250.

Mantri N., Patade V., Penna S., Ford R. and Pang E. (2012) Abiotic stress responses in plants: Present and future. In: Ahmad P. and Prasad N. V. Abiotic Stress Responses in Plants: Metabolism, Productivity and Sustainability. New York: Springer: 1-19.

Mengel K. Kirkby E. A., Kosegarten H. and Appel T. (2001) Principles of plant nutrition. Kluwer, Dordrecht.

Khush G. S. (2005) What will it take to feed 5.0 billion rice consumers in 2030? Plant Mol Biol59: 1-6.

Panse V. G andShukhatme P. V. (1967) Statistical Methods for agricultural workers, $2^{\text {nd }}$ edition, ICAR, NewDelhi.,
152-157.

Press information Bureau, Government of India, June, 2017.

Sandhya, Alok K., Rn gare N. R. and Vidyakar V. (2015) Study of genetic variability of Indian and exoticrice germplasm in Allahabad agroclimate. The Bioscan. 8(4):1345- 135.

Sandhya, Babu S. G. and Kumar R. (2014) Genetic Variability, Interrelationship and Path Analysis for Yield Improvement of Rice Genotypes. The Bioscan. 9 (3):1161-1164.

Tiwari R., Suresh B. G., Mishra V. K. and Kumar A. (2011) Genetic variability and character association in direct seeded upland rice (Oryza sativa L.). Environment and Ecology. 29 (4A): 2132-2135.

USDA-ARS (2008) Research Databases Bibliography on Salt Tolerance. George E. Brown, Jr. Salinity Lab. US Dep. Agric., Agric. Res. Serv. Riverside, CA.

Zeng L., Lesch S. M. and Grieve, C. M. (2003) Rice growth and yield respond to changes in water depth and salinity stress. Agri Water Manage 59: 67-75.

\section{How to cite this article:}

Anuj Kumar, D. K. Dwivedi, Pradeep K. Bharti, Vineeta Singh, Preeti Kumari, Archana Devi, and Khan, N. A. 2020. Evaluation of Rice Genotypes for Genetic Variability, Heritability and Genetic Advance in Saline and Normal soil Conditions. Int.J.Curr.Microbiol.App.Sci. 9(07): 2714-2721. doi: https://doi.org/10.20546/ijcmas.2020.907.320 